\title{
A COMPARATIVE ANALYSIS OF TIME, COST AND RISK APPROACHES IN ROMANIAN AND ICELANDIC ENVIRONMENTAL PROJECT MANAGEMENT
}

\author{
Cezar-Petre SIMION ${ }^{a *}$, Camelia DRAGHICI ${ }^{b}$, Mihai VRINNCUT, $^{c}$, \\ Daniel-Constantin JIROVEANU ${ }^{d}$, Florin ANGHEL ${ }^{e}$ \\ a,c,d,e Bucharest University of Economic Studies, Romania \\ ${ }^{b}$ Transilvania University of Brașov, Romania
}

\begin{abstract}
The research presented in this article had as main objective the comparative analysis of the way in which the project management is carried out in Romania and in Iceland. Environmental projects from each country were selected and based on the available documentation the main components of their management were analyzed. The analysis seems to indicate a relatively frequent use of classical methods of programming project execution without identifying the use of modern methods neither in the case of environmental projects in Romania, nor in the case of those in Iceland. In terms of cost management, budgeting is more frequently used and in terms of risk management, risk identification is more common in Romania and in the case of Iceland the other components of the risk management process.
\end{abstract}

KEYWORDS : management, project, environment, time, risk, cost

\section{INTRODUCTION}

Human activity has had a significant impact on the environment in most parts of the world, materialized in many ecological problems. The issue of the environment and especially the ecological one gradually came to the attention of society especially against the background of raising awareness in the perception of global warming (Luque et al, 2013) ozone depletion, biodiversity loss, air pollution, toxic waste or ecological accidents (Sholarin and Awange, 2015). Moreover these ecological problems have affected all components of the environment: soil, water, air, all life forms. Both Romania and Iceland were affected by the environmental problems, whether they were of local origin or they were consequences of global problems. The European Commission's country report shows that Romania is facing several environmental problems:

- efficient recycling and waste management are at a low level compared to other EU countries;

- poor air quality (the main sources of air pollution from the transport and energy sectors - the use of solid or liquid fuels in households);

- water quality (wastewater treatment and quantity / quality of drinking water);

Iceland is affected by global warming and climate change, with extensive use of natural resources, the case of the fishing industry being one of the most relevant.

Addressing environmental issues around the world has given rise to specific projects that take into account the protection, conservation and remediation of the environment. Environmental pollution is a first factor that imposed the need for environmental projects, followed by the implementation of specific projects for environmental protection. The amplification of the public perception of the

\footnotetext{
* Corresponding author. E-mail address: cezar.simion@man.ase.ro
} 
environmental issues created the need to develop projects in this field both in Romania and in Iceland.

The purpose of this research is to reveal the specific elements of environmental projects in Romania and Iceland, in a comparative approach that reveals the elements of improvement in managerial practices in environmental projects in both countries. The research has the following objectives:

- to identify the relevant sources regarding the environmental projects conceived and implemented in Romania and Iceland but also in other countries;

- to perform an analysis that reveals the most important methods and techniques of project management applied in environmental projects in Romania and Iceland;

- lead to a series of elements that can be improved through education / training / examples of good practice in both countries.

In order to achieve the objectives, the research presented in this article had to provide answers to the following questions:

- what are environmental projects?

- what are the main types of environmental projects implemented in Romania, in Iceland but also in other countries in the world?

- what elements of project management are implemented in environmental projects in Romania and Iceland?

- what methods and techniques are not used (or are not used to a significant extent) and could be implemented in the future in environmental projects carried out in Romania and Iceland?

The research presented in this article represents a first step in a broader comparative cycle that considers the management of environmental projects in Romania and Iceland. However, so far, there is no other similar research initiative that takes into account both environmental projects in Romania and those in Iceland.

\section{LITERATURE REVIEW}

The approach to environmental issues differs greatly in the literature from their definition. Sholarin and Avange (2015) define environmental projects as those that are intended for the environment by their nature, have specific activities in the field of environment and results on sustainability. The same authors consider that environmental projects are those that have objectives in the area of sustainability and the management of environmental projects involves three elements: management, project and environment. Sholarin and Avange also made a distinction between environmental project management and green project management - promoted by Maltzman and Shirley (2012) and Mochal and Krasnoff (2010) - which involves assimilating the organization's environmental policies into project management processes. Jolly (1978) considers that environmental management is "process of allocating natural and artificial resources so as to make optimum use of the environment in satisfying basic human needs at the minimum, and more if possible, on a sustainable basis".

Most studies in the literature that focus on environmental projects rarely focus on the management of these types of projects but only certain aspects of it. Urton and Murray (2021) analyzed the process of collaboration in multidisciplinary environmental management projects from the perspective of project managers, starting from previous results published in the field of project management and environmental management. They identified a number of common elements in the two areas of study that facilitate collaboration in multidisciplinary environmental management projects but also a number of differences (the field of project management is more focused on collaborations in private projects and the field of environmental management is tended to favor public sector approaches). 
Many studies and research published internationally on environmental projects are focused on certain aspects of their definition, substantiation and implementation. This category includes research whose main topic is environmental impact analysis of the projects conducted by Geneleti, Biasiolli and Morrison-Saunders (focused on environmental imact assessment) or van Eldik et al. (2020). From the perspective of using project management methods and techniques in the case of environmental projects, an interesting approach is the one proposed by Abdi, Taghipour and Khamooshi (2018) on a model to control environmental performance of project execution process based on greenhouse gas emissions using earned value management. Their study demonstrates how a project management-specific technique such as Earned Value Analysis can be used applied to the particular case of a specific environmental project (to predict GHG emissions at the end of the project).

Specific projects in the field of research or environmental education are also addressed in the literature. An example in this field is the study published by Gkiolmas et al. al (2020) which, however, has fewer valences in terms of elements specific to project management. Another relevant study from this point of view, but intended for environmental research projects is the one published by Calik et al. (2012). There are relatively few studies in the literature dedicated to environmental projects in Iceland and their management. In terms of project management, published studies are conducted from a general perspective rather than focusing on the specifics of environmental projects. The comparative approach (Germany, Norway, Iceland) of economic design in the study conducted by Schoper et al. (2018) is significant for those mentioned above. Although the results of the study conducted by Schoper et. al (2018) shows that Iceland lags behind Germany and Norway in terms of projecting the economy an important part of the economic activities in this country are based on projects $(27.7 \%)$. This places Iceland among the countries that are at a higher level in the development of project management and in its application in practice, although at the time of this study there were significant differences between various sectors of activity (the manufacturing sector being one in which project management was very poorly represented, largely due to the specifics of the activity in this field). Other studies on environmental projects in Iceland address the issue of environmental impact of projects and ways of assessing it (environmental impact analysis / assessment, life cycle analysis). This category includes research conducted by: Cook, Davíðsdóttir and Kristófersson (2016); Sigurjonsson et al. (2021); Shortall, Davidsdottir and Axelsson (2015). There are studies dedicated to environmental projects in Iceland which note the existence of a possible impact on the environment even in the case of such projects. An example in this regard is that made by Ingolfsdottir and Gunnarsdottir (2020) on the conflict of interest between renewable energy projects and wilderness protection in Iceland. In Romania, studies conducted on environmental project management are relatively few and do not necessarily address issues regarding project management but certain aspects of defining and substantiating this type of project, most often the impact of these projects on the environment. Significant from this point of view are the studies conducted by Cormos (2014) aimed at technical-economic assessments of an environmental project and those conducted by Costea et al. (2021) on the impact of a certain type of projects (hydropower plants) on the environment. It is noted in the study conducted by Costea et al. (2021) that $49 \%$ of hydropower plants are placed in Natura 2000 sites and that it largely affects aquatic biodiversity. Studies on project management in Romania are rather general and do not focus on environmental projects. According to research conducted by Gareis and Huemann (2019) in Romania, project management still has a relatively limited scope of applicability to a range of industry sectors and industries that are traditionally project-oriented.

The analysis of the literature reveals that both in Romania and in Iceland the research on environmental projects was conducted from the perspective of aspects, methods and techniques focused on the impact of this type of project on the environment without a focus on methods and techniques specific to project management. 


\section{RESEARCH METHODOLOGY}

The research aimed at a comparative analysis of project management in Romania and Iceland to help find those aspects that are already implemented in these types of projects in the two countries and those that can be improved through education or training.

For this, ten environmental projects from each country were selected for which the documents that are public were analyzed (funding applications, opportunity studies, pre-feasibility and feasibility, other project funding documents, project progress reports). The size of the sample of analyzed projects is relatively small, the main cause being the relatively small number of related documentation from which to extract the data necessary for their realization. The criterion used in the selection of projects was that of ensuring a diversified typology of environmental projects.

For the analysis of the way in which the management of environmental projects is performed, the following components were selected for study: time management, cost management and risk management. The choice of these components for the study was made because they are most easily found in documents that are public and represent fundamental elements in terms of project management.

For each of the components, a Romania-Iceland comparative analysis was performed, taking into account the need to establish a series of common elements that the management of environmental projects has in both countries.

\section{RESEARCH RESULTS}

In the research carried out, projects for elimination of pollution, projects for pollution prevention, projects for regeneration of the natural environment, projects for waste collection, waste recycling projects were taken into account. The structure of the sample of analyzed projects for both Romania and Iceland is presented in the Table 1.

Table 1. The structure of the analyzed projects

\begin{tabular}{|l|l|c|c|}
\hline No. & \multicolumn{1}{|c|}{ Project type } & Romania & Iceland \\
\hline 1 & Projects for pollution reduction & $40 \%$ & $30 \%$ \\
\hline 2 & $\begin{array}{l}\text { Projects for pollution } \\
\text { prevention }\end{array}$ & $30 \%$ & $30 \%$ \\
\hline 3 & $\begin{array}{l}\text { Projects for regeneration of the } \\
\text { natural environment }\end{array}$ & $10 \%$ & $20 \%$ \\
\hline 4 & $\begin{array}{l}\text { Projects for waste collection } \\
\text { and recycling }\end{array}$ & $100 \%$ & $100 \%$ \\
\hline & Total & $20 \%$ \\
\hline
\end{tabular}

Source: own calculations based on project documentations

As can be seen from the table above, most of the projects analyzed (about two thirds in the case of both countries) are those on prevention of pollution and pollution reduction. Projects for waste collection and recycling are equally represented in both countries in the research conducted. In the case of projects in Iceland, projects for regeneration of the natural environment are better represented. Regarding time management, the presence in the project documentation of the main component processes was analyzed. The results are shown in the Figure 1.

From the Figure 1 it can be seen that environmental projects carried out in Romania have a better representation of the processes that lead to the identification of project activities while similar projects 
carried out in Iceland have higher weights in terms of representation of project execution programming. More important is the process of monitoring the execution of projects in the case of environmental projects implemented in Iceland.

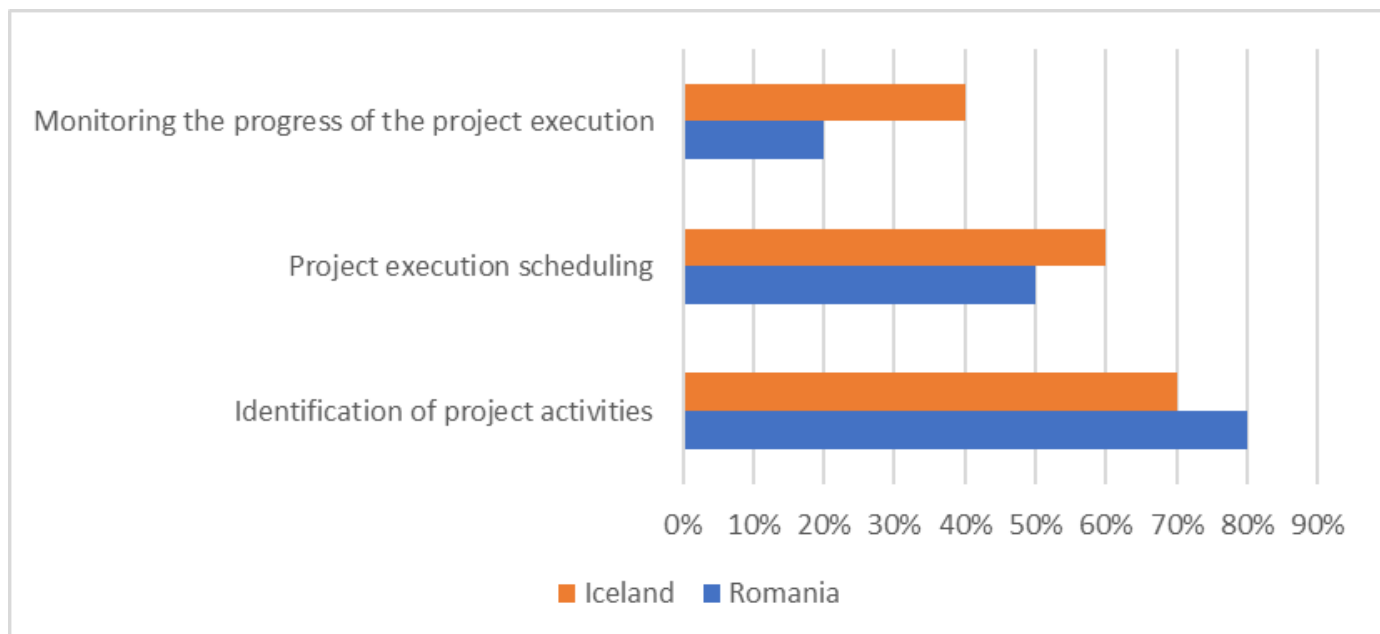

Figure 1. Time management processes in environmental projects in Romania and Iceland Source: own calculations based on project documentations

A relatively similar situation is encountered in the case of methods and techniques applied for time management. The results on the application of these methods and techniques are presented in the Table 2.

Table 2.Methods and techniques applied for time management of environmental projects in Romania and Iceland

\begin{tabular}{|c|l|c|c|}
\hline No. & \multicolumn{1}{|c|}{ Project type } & Romania & Iceland \\
\hline 1. & Gantt chart & $50 \%$ & $60 \%$ \\
\hline 2. & Milestone chart & $10 \%$ & $0 \%$ \\
\hline 3. & $\begin{array}{l}\text { Modern methods: Critical Path } \\
\text { Method (CPM), Program }\end{array}$ & $0 \%$ & \\
& $\begin{array}{l}\text { Evaluation and Review } \\
\text { Technique (PERT) and }\end{array}$ & & \\
& $\begin{array}{l}\text { Graphical Evaluation and } \\
\text { Review Technique (GERT) }\end{array}$ & \\
\hline
\end{tabular}

Source: own calculations based on project documentations

From Table 2 it can be seen that the most used method of scheduling the execution of projects is the Gantt chart for environmental projects carried out in both countries. This is not surprising since most projects, regardless of the field of activity, use this form of scheduling execution over time. One explanation could be, as in the case of other types of projects, that the application of the method is intuitive and relatively easy to use even by staff who do not have knowledge or experience in the field of project management. Modern methods (PERT and GERT) have not been identified in environmental project documentation because they are methods used mainly in design and engineering projects or research projects.

Another element of project management analyzed in the research was the one related to cost management. The results are presented in the Figure 2.

As can be seen from Figure 2 for all categories of cost management processes, environmental projects in Iceland have higher weights in terms of resource planning and cost estimation. Environmental 
projects in Romania have higher weights in terms of cost budgeting and control. The situation can be explained by the fact that the number and scope of documentation on the management of environmental projects in Romania was much higher than in the case of projects in Iceland.

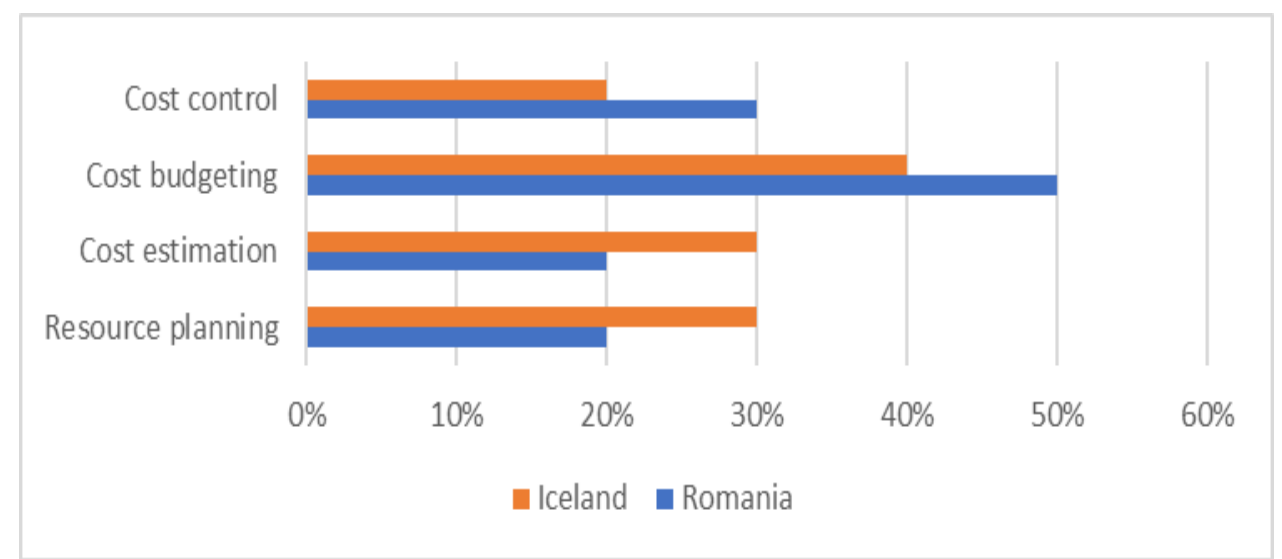

Figure 2. Cost management processes in environmental projects in Romania and Iceland Source: own calculations based on project documentations

Another important aspect in terms of environmental project management is risk management. The results regarding the specific risk management processes are presented in the Figure 3.

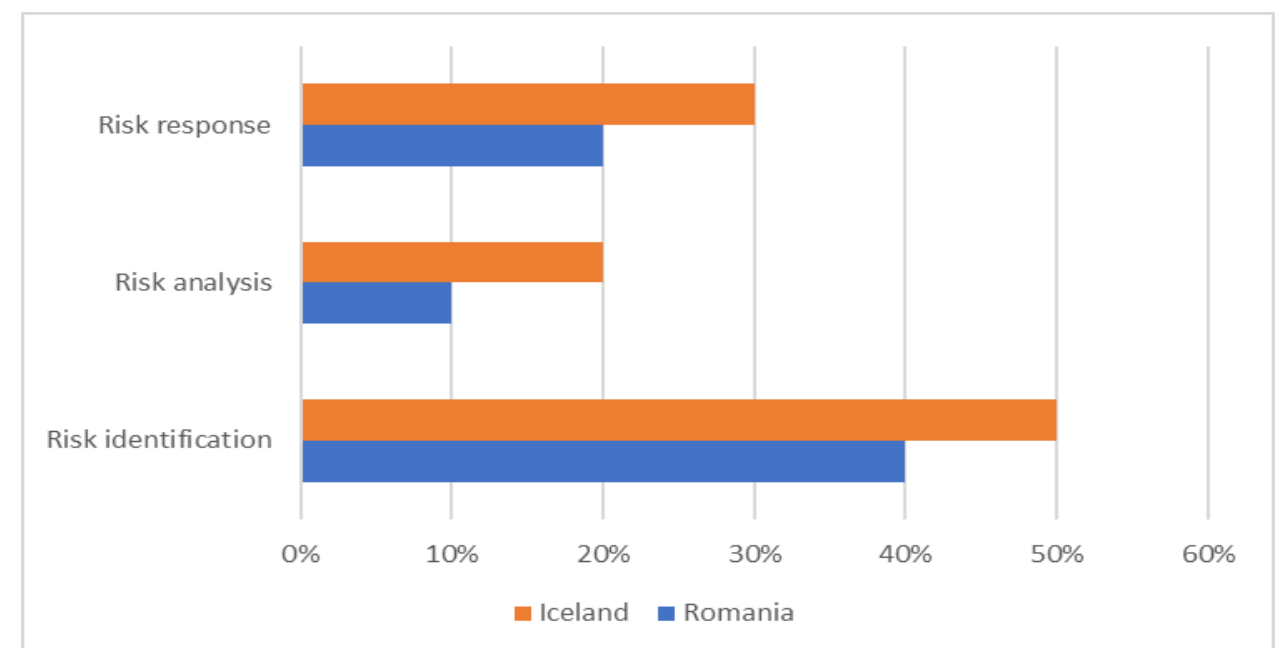

Figure 3. Risk management processes in environmental projects in Romania and Iceland Source: own calculations based on project documentations

It is noted that in the case of environmental projects carried out by both countries, the risk identification process is better represented. On the one hand it is required as such in most environmental projects and related documentation and it is the risk management stage that requires the least knowledge regarding the applicable techniques.

The other components of the risk management process (risk analysis and risk response) can be improved in both countries, through specific actions in education and training in project management, to be used to improve the performance of staff involved in environmental projects. In order to perform the risk analysis, at least the following methods and techniques should be known and applied by the personnel involved in the realization of the projects: probability-impact matrix; risk map; sensitivity analysis. 
Another important element is that the risk management process does not only target environmental risks but all the risk factors that can affect an environmental project throughout its life-cycle:

- macro-risks and micro-risks of an economic and financial nature,

- operational risks and technological,

- political and regulatory risks,

- interface risk between project participants.

It is not only risk management processes that need to be the subject of education and training actions to improve them. Equally, staff involved in environmental projects should be able to assimilate through education and training advanced methods of project execution programming (CPM, PERT, GERT) or important components of project cost management. The fact that the analyzed projects use only classical methods of programming the execution of projects over time demonstrates that empiricism still predominates and there is enough place for improvement in the management of environmental projects in both countries.

\section{FUTURE PERSPECTIVES}

A good opportunity to improve environmental education and environmental projects is represented by the project "Environmental Education - OERs for rural citizens (EnvEdu-OERs)" developed in partnership by Transsylvania University of Brașov, Reykjavik University, Bucharest University of Economic Studies and "Gheorghe Asachi" Technical University of Iași. The project aims at environmental education, developing a set of teaching modules as open educational resources (OERs) available to a wide range of beneficiaries, especially those from rural areas. Within this project, six teaching modules will be developed on the following topics:

- social communication in sustainable rural communities;

- environment quality;

- environmental management, impact and risk assessment;

- waste management in rural communities

- water resources and water balance for sustainable community

- environmental projects management

The module dedicated to environmental projects management will have as main topics: phases of environmental projects, time management, cost management, resources management, risk management and good practice examples. It can be seen that the main topics of the module are dedicated to those components of environmental project management that can be improved by training participants in their implementation both in Romania and in Iceland.

\section{CONCLUSIONS}

The research aimed at conducting a comparative analysis of how environmental projects are carried out in Romania and Iceland, in order to identify the main elements applied in time management, cost management and project quality management. For this purpose, the documentations of several types of environmental projects were studied: projects for elimination of pollution, projects for pollution prevention, projects for regeneration of the natural environment, projects for waste collection and recycling.

In the case of environmental projects carried out in Romania, the process of identifying activities is better represented, while in the case of projects carried out in Iceland, the other two components of time management are better represented. However, in the case of projects carried out in both countries, only the classical methods used in the programming of project execution are used (at least in the analyzed documentation). No cases of use of modern methods of programming project 
execution (CPM, PERT or GERT) were identified in the analyzed documentation on projects in both countries.

In the case of projects in both countries, project budgeting is better represented and less so the other components of project cost management. A possible cause is the fact that most of the analyzed documents focused mainly on the project definition and planning stage and less on the actual implementation phase. Regarding the risk management, in the environmental projects realized in Romania is better represented the risk identification phase and less the analysis and response ones (which are more present in the case of the projects realized in Iceland).

In the case of projects in both countries, project budgeting is better represented and less so the other components of project cost management. A possible cause is the fact that most of the analyzed documents focused mainly on the project definition and planning stage and less on the actual implementation phase. Regarding the risk management, in the environmental projects realized in Romania is better represented the risk identification phase and less the analysis and response ones (which are more present in the case of the projects realized in Iceland).

ACKNOWLEDGMENT: to the project "Environmental Education - OERs for rural citizens (EnvEdu-OERs)" funded with the support from the Education, Scholarschips, Apprenticeships and Youth Entrepreneurship Programme (ESAYEP), EEA Grants 2014-2021

\section{REFERENCES}

Abdi A., Taghipour S., Khamooshi H. (2018) A model to control environmental performance of project execution process based on greenhouse gas emissions using earned value management, International Journal of Project Management, 36( 3), 397-413

Calik M., Ozsevgec T., Kucuk Z., Aytar A., Artun H., Kolayli T., Kiryak Z., Ultay N., Burcin T., Ebenezer J., Costu B. (2012) Analyzing Senior Science Student Teachers' Environmental Research Projects of Scientific Inquiry: a Preliminary Study, Procedia - Social and Behavioral Sciences, 46, 379-383

Cormos C.C. (2014) Techno-economic and environmental evaluations of large scale gasificationbased CCS project in Romania, International Journal of Hydrogen Energy, (39) 1, 13-27

Costea G., Pusch M., Bănăduc D., Cosmoiu D., Curtean-Bănăduc A. (2021) A review of hydropower plants in Romania: Distribution, current knowledge, and their effects on fish in headwater streams, Renewable and Sustainable Energy Reviews, 145, 2021, 111003

Cook D., Davíðsdóttir B., Kristófersson D. M. (2016) Energy projects in Iceland - Advancing the case for the use of economic valuation techniques to evaluate environmental impacts, Energy Policy, 94, 104-113

Gareis R. , Huemann, M. (2019). Assessing and Benchmarking Project-oriented Societies.

Geneletti D., Biasiollia A., Morrison-Saunders A. (2017). Land take and the effectiveness of project screening in Environmental Impact Assessment: Findings from an empirical study, Environmental Impact Assessment Review, 67, 117-123

Gkiolmas A., Dimakos C. , Chalkidis A., Stoumpa A.(2020) An environmental education project that measures particulate matter via an Arduino interface, Sustainable Futures, 2, 100027

Ingolfsdottir A., Gunnarsdottir G., - Tourism as a tool for nature conservation? Conflicting interests between renewable energy projects and wilderness protection in Iceland, Journal of Outdoor Recreation and Tourism, 29 (2020) 100276

Jolly V (1978) The concept of environmental management development. Foram, 8(2), 13-26

Luque, G.M., Hochberg, M.E., Holyoak, M., Hossaert, M., Gaill, F., Courchamp, F. (2013) Ecological effects of environmental change, Ecol. Lett, 16.

Maltzman R., Shirley D. (2012) Green project management. CRC Press, Boca Raton 
Mochal T, Krasnoff A (2010) Green project management: supporting ISO 14000 standard through project management process [electronic version]. http://greeneconomypost.com/greenproject management-greenpm-iso-14000-11040.htm

Schoper Y.G., Wald A., Thor Ingason H., Fridgeirsson T.V., Projectification in Western economies: A comparative study of Germany, Norway and Iceland, International Journal of Project Management, 36 (1),2018, 71-82

Sigurjonsson H.E, Cook D., Davíðsdottir B., Bogason S.G (2021) A life-cycle analysis of deep enhanced geothermal systems. The case studies of Reykjanes, Iceland and Vendenheim, France, Renewable Energy, 177, 1076-1086

Sholarin E., Awange J. (2015) Environmental Project Management. Principles, Methodology and Processes, Springer

Shortall R., Davidsdottir B., Axelsson G. (2015) A sustainability assessment framework for geothermal energy projects: Development in Iceland, New Zealand and Kenya, Renewable and Sustainable Energy Reviews,50, 372-407

European Commission - The Environmental Implementation Review 2019, Country report Romania

Urton D., Murray D. (2021) Project manager's perspectives on enhancing collaboration in multidisciplinary environmental management projects, Project Leadership and Society, 2, 100008

Van Eldik M.A, Vahdatikhaki F., Oliveira dos Santos J.M., Visser M., Doree A. - BIM-based environmental impact assessment for infrastructure design projects, Automation in Construction 120 (2020) 103379 